\title{
接合部詳細の違いに着目した引張ブレース付き柱梁部分架構の実験 \\ EFFECTS OF DIFFERENCES IN CONNECTION DETAILS \\ ON STRUCTURAL BEHAVIOR OF BEAM-COLUMN SUBASSEMBLY WITH BRACE
}

\author{
吉敷祥 一*, 近藤 直 弥**, 山田 哲***, 長谷川 隆**** \\ Shoichi KISHIKI, Naoya KONDO, Satoshi YAMADA \\ and Takashi HASEGAWA
}

\begin{abstract}
The majority of the previous studies on braced-frame structures have tested isolated braces or simple subassemblages which neglect the influence of the framing components and the gusset-plate connection on the system performance. In this paper, cyclic loading tests of 9 beam-column subassemblages with an angle brace to investigate effects of the differences in connection details on structural behavior of the braced-frame system.

From the experiments, a decrease in the initial stiffness of the whole frame and the insufficient strength caused by the unexpected failure modes of the connection are obtained. Based on the comparison with the test results, the simplified evaluation models considering effects of the local deformation and plasticity due to the eccentric brace connections are proposed.
\end{abstract}

Keywords : brace, gusset plate, connection, beam column subassemblage, cyclic loading ブレース, ガセットプレート, 接合部, 柱梁部分架構, 繰り返し載荷

1. はじめに

工場や屋内運動場といった大空間を構成する低層の鋼構造建築物 では, 柱にH形断面を用い, 柱強軸方向には梁を剛接合した純ラー メン構造を,柱弱軸方向には梁をピン接合した上で圧縮抵抗を期待 しない引張ブレースを配した純ブレース構造を採用することが多 い.ブレース全般に関しては1970，80年代頃に活発な研究1) 8)なと が行われ, 復元力特性モデルの構築1) 3)などや接合部の性能把握4) 6)などが精力的に取り組まれた. 特にブレース端接合部の設計につい ては, 山形鋼などの無効突出脚やガセットプレートの有効断面を考 慮した保有耐力接合としての設計が新耐震設計法の施行とともに実 施されるようになり,その効果は近年の地震被害調查において実証 されつつある尔な゙。

一方, 架構全体で周辺部材を含めたブレース端部に着目すると, この部位には柱, 梁, ブレースの3 部材が集結し, 柱梁接合部, ブ レース端接合部, および補剛スチフナが複雑に配置されることが分 かる. また, H形断面柱の弱軸方向では, 梁端のピン接合部をウェ ブのみを現場で高力ボルト摩擦接合して実現することが多く, 現場 での施工性を優先にしたディテールを採用する傾向にある.実際の

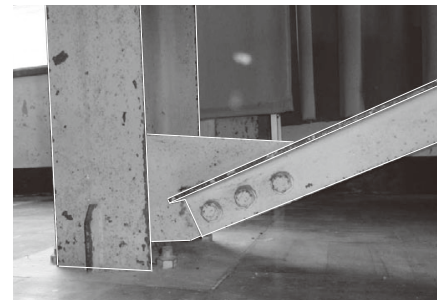

(a) 片持ちガセット

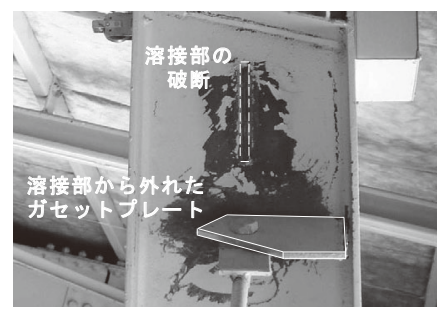

(a*) 片持ちガセットの被害

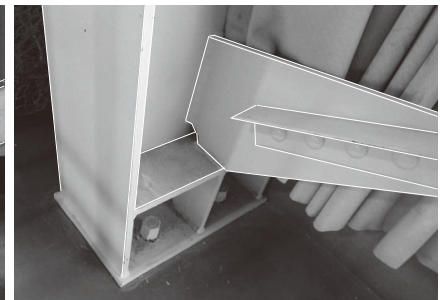

(b) 偏心ディテール

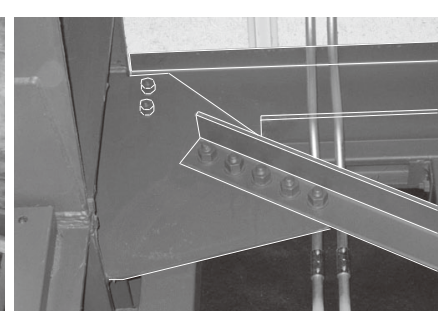

（c）兼用ガセットプレート
図1引引張ブレース構造の接合ディテール

接合ディテールを図1に例示する.図1 (a) ではブレース端接合部を 柱から張り出して片持ち梁状に取り付けており,図1(b)ではブレー

\footnotetext{
* 東京工業大学 建築物理研究センター 准教授・博士 (工学)

** 元東京工業大学大学院 修士(工学)

*** 東京工業大学 建築物理研究センター 教授・博士 (工学)

**** 建築研究所 構造研究グループ 主任研究員・博士 (工学 $)$
}

Associate Prof., Structural Engineering Research Center, Tokyo Institute of Technology, Dr.Eng.

Former Grad. Stud., Tokyo Institute of Technology, M.Eng.

Prof., Structural Engineering Research Center, Tokyo Institute of Technology, Dr.Eng.

Senior Researcher, Structural Engineering Dept. Building Resarch Institute, Dr.Eng. 
スを柱の鉛直方向に偏心させて取り付けている.また, 図1 (c) はブ レース端と梁端の接合部を兼礼たものである.このように, 実際に は多様な接合ディテールが存在している.一方, 近年の被害調查で は,ブレース端の高力ボルト接合部における破断は回避されたが, 柱の局所的な降伏を伴うガセットプレート端溶接部の破断(図 1 $\left.\left(\mathrm{a}^{*}\right)\right)$ が観察されている.このような種々のディテールが保有する 性能の検証が必要であるが, 我が国では柱梁を含めたブレース端接 合部を忠実に再現した実験7, 8) な゙が少なく, 接合ディテールの違い が架構全体の力学挙動に及ぼす影響の把握も必要である.

本論文では, 柱梁を含むブレース端の接合ディテールをパラメー タとした引張ブレース付き柱梁部分架構 (以後, 部分架構) の載荷実 験を行い, 接合ディテールの違いが部分架構の力学挙動に与える影 響を把握する.また, 接合部を破壊させる試験体を含めた実験結果 から, 接合部の最大耐力や破壊状況を把握し, 接合部設計の発展に 資する基礎データを得る。

\section{2. 実験計画}

\section{1 実験対象とする架構の概要}

試験体の対象部位と部材リストを図 2 に示す. 実験ではスパン, 階高ともに $4.2 \mathrm{~m}$ の柱梁に, X形にブレースを配した構面を対象と 寸る. 試験体は, 柱, 梁, ブレースをそれぞれの材中央で切り出し たL字形部分架構とし, 切り出し位置を柱梁は反曲点としてピン支 持し,ブレースはガセットプレートを介して載荷治具に接続する. なお, 対象構面の直交方向から接続する梁を想定した場合, 柱のス チフナ補強が接合部内に含まれる図2の右上側の接合部を本実験で は対象とし, 対象部分を180度回転して載荷を行う。

試験体の柱と梁には, H400x200x8x13の弱軸使い, H300x150の 強軸使いをそれぞれ用いる.梁端をピン接合とする場合には, 高力 ボルト3-M20（F10T) をピッチ $60 \mathrm{~mm}$ で用い, 柱等に溶接されたガ セットプレートに梁ウェブのみを摩擦接合する.

ブレースには, 材長が約 $2.2 \mathrm{~m}$ の等辺山形鋼L90x90x7を背合わせ の 2 丁使いで用いる.ブレース端部は高力ボルト 5-M16(F10T)を ピッチ $60 \mathrm{~mm}$ でガセットプレートに接合し, さらに両材端接合部の ボルト間距離を3等分する2点に綴りボルト (M16(F10T)) を設けて いる.なお,ブレースは, 試験体の破壊状況を確認するため, 一部 の試験体で軸部降伏耐力が接合部耐力を上回る断面を選定してい る. また, 本実験で想定したX形ブレースでは, ブレースの一方が 座屈する際には他方に引張力が働いているため, 交叉部では面外 の移動が拘束され, ブレースの座屈長さは全長の半分程度になると 考えられる. 本実験装置では常に交叉部の面外変位が拘束される境 界条件にあるため, 2丁使いの山形鋼の細長比は, 接合部を含む山 形鋼材端部を両端ピン支持とした場合に $\lambda=79.7$ となる.この細長 比は, 一般的な引張ブレースが属するFBランクの範囲 (>129, ただ $\left.L_{F}=235 \mathrm{~N} / \mathrm{mm}^{2}\right)^{10)}$ に対して, 小さい設定となっている.

\section{2 載荷装置}

実験のセットアップを図3に, 載荷システムの概要を図4に示寸. 試験体は, 柱下端と梁自由端を水平移動が自由なピン・ローラー治 具により支持するとともに, 梁自由端では水平反力治具に接続して 反力フレームに固定する. 載荷は, $1000 \mathrm{kN}$ 油压ジャッキを柱脚ピ ンの独立柱, 水平加力治具を介して試験体に接続し, 柱頭部に強制
変形を与えることで行う.独立柱は試験体の梁を跨ぐように2本設 置した部材を連結して構成し, 柱脚ピンから加力高さまでの回転半 径を試験体の高さと一致させている.したがって,ブレースの一端 を柱梁交叉部に接合し, 他端を独立柱に接続することで, ブレース には柱梁架構の層間変形とほぼ同程度の水平変位を生じさせること ができる.なお, 独立柱側のガセットプレート(付図1) は, 構面外

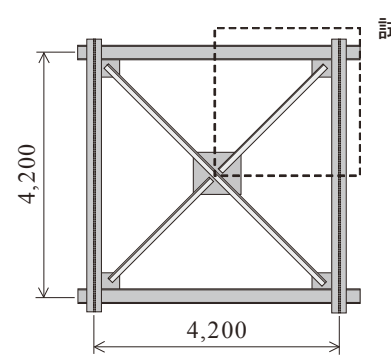

試験体の対象部位 (180 度回転して設置)

部材リスト

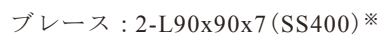

柱: RH400x200x8x13 (SM490A) 弱軸

梁: RH300x150x6.5x9（SS400）

BH300x150x9x12(SS400)

※ 背合わせの 2 丁使いとする

図2試験体の対象部位と部材リスト

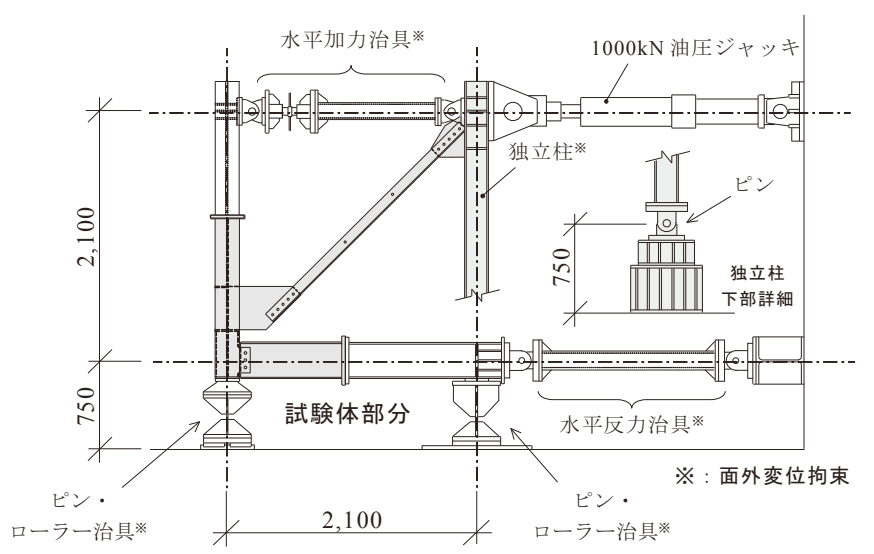

図3 セットアップ

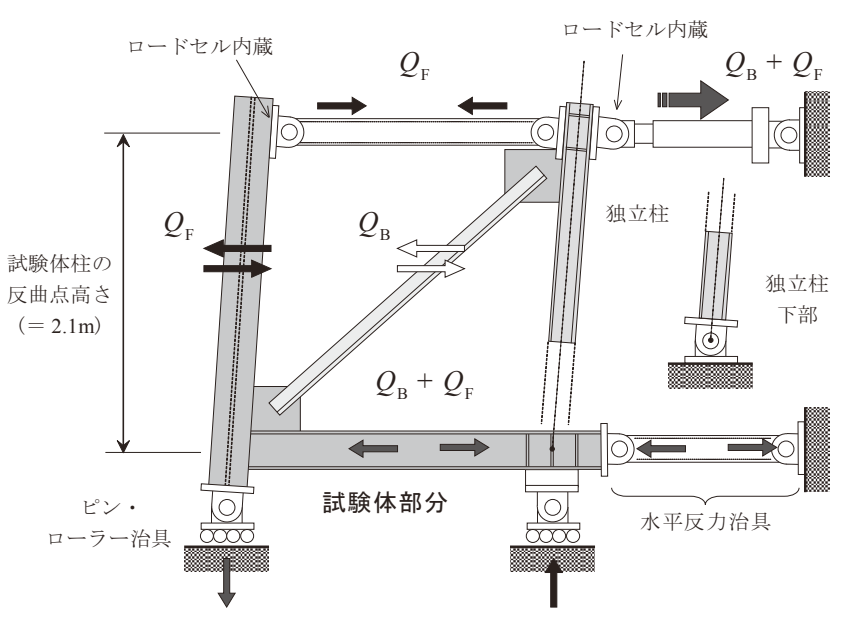

図4載荷システムの概要

表1 試験体一覧

\begin{tabular}{|c|c|c|c|c|c|}
\hline & 試験体 & 梁断面 & 梁端接合部 & ブレース端ガセッ卜 & その他 \\
\hline a & a & 圧延 & ピン & 柱のみに溶接 & \\
\hline \multirow{2}{*}{$\mathrm{b}$} & b-1 & 圧延 & ピン & 柱のみに溶接 & 偏心あり \\
\hline & b-2 & 圧延 & 剛 & 柱のみに溶接 & 偏心あり \\
\hline \multirow{3}{*}{ c } & $\mathrm{c}-1$ & 圧延 & ピン & 梁端ガセッと一体 & \\
\hline & $c-1 R$ & 圧延 & ピン & 梁端がセッと一体 & c-1の梁端ガセ外を面外補強 \\
\hline & $\mathrm{c}-2$ & 压延 & ピン & 梁端がセッと一体 & c-1のブレース端がセ外有効断面を縮小 \\
\hline \multirow{3}{*}{ d } & d-1 & 溶接組立 & 剛 +ピン継手 & 柱梁に溶接 & ブレース端ガセッ忙c-1と同一形状 \\
\hline & $\mathrm{d}-1 \mathrm{C}$ & 溶接組立 & 剛＋ピン継手 & 柱梁に溶接 & d-1のブレース端がセット最小化 \\
\hline & $\mathrm{d}-2$ & 溶接組立 & 剛＋ピン継手 & 柱梁に溶接 & ブレース端ガセットはc-2と同一形状 \\
\hline
\end{tabular}


への回転を拘束せず,かつ接合部が破壊しないよう設計している. 本載荷方法では, 柱下端をピン・ローラー支持とすることで, 部 分架構のせん断力をすべて梁に伝達させている.これは, 試験体の 対象部位の上部に同様のブレース構面がある連層配置を想定し, ブ レース軸力の反力として梁が圧縮軸力を負担することを極力再現す るためである.ただし, 実際には, 実験対象のブレースが座屈して いる際にも, 対となるブレースの引張抵抗によって梁には圧縮軸力 が作用するが, この軸力の作用については再現できていない.
ロードセルにより部分架構全体の層せん断力 $\left(Q_{\mathrm{B}}+Q_{\mathrm{F}}\right)$, 柱梁架構 の負担水平力 $Q_{\mathrm{F}}$ を計測し, 両者の差分からブレースの負担水平力 $Q_{\mathrm{B}}$ を得る.併せてピン・ローラー支承部における鉛直変位による回 転成分を除去した部分架構の層間変形角 $R$,および各部材断面のひ ずみ度を計測した。なお, 独立柱, 水平加力治具, 水平反力治具は 紙面直交方向に2つの部材を併設しており, 柱下端と梁自由端の板 曲げを利用したピン治具を含め,これらの位置において試験体の面 外変位を拘束している。

実験中は油圧ジャッキと水平加力治具のピン部分に組み込んだ

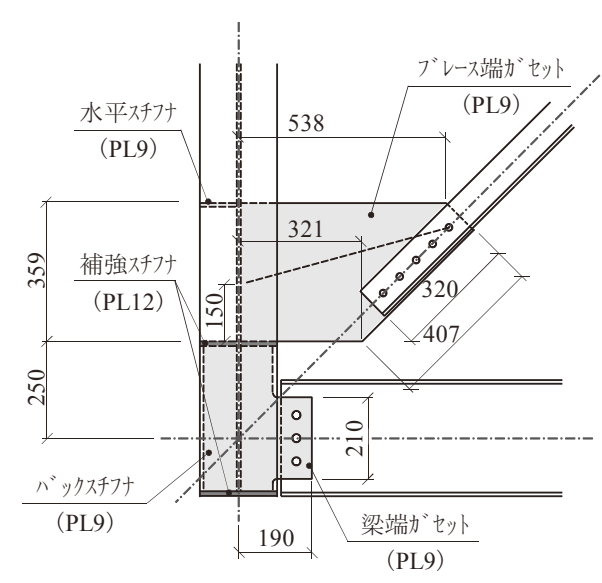

(1) 試験体a（片持ちガセット）

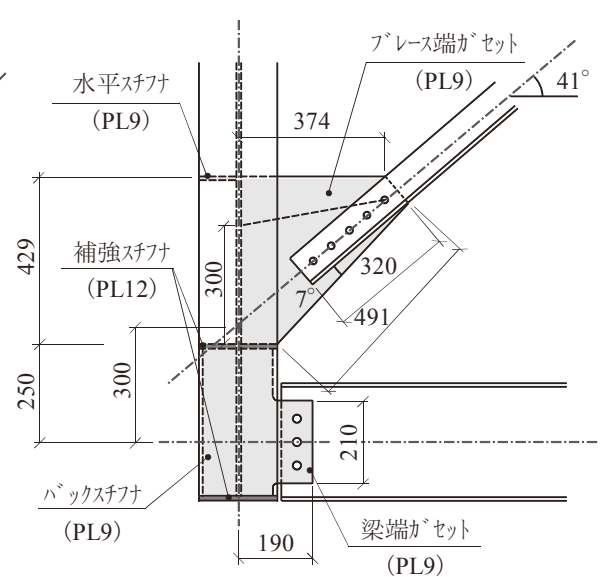

(2) 試験体 b-1（偏心・梁端ピン）

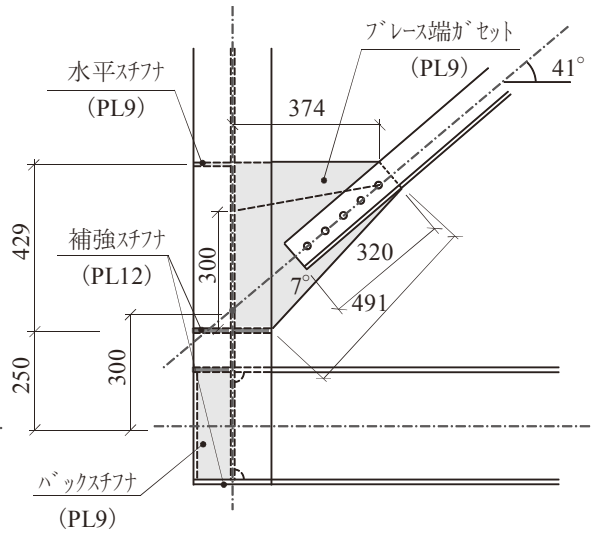

(3) 試験体 b-2（偏心 ・梁端剛）

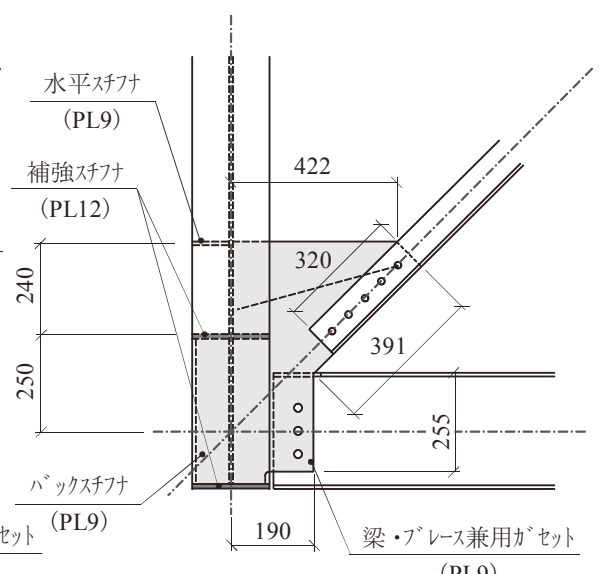

(6) 試験体 c-2（兼用接合部・梁側カット）

（4）試験体 c-1（兼用接合部）

(5) 試験体 c-1R（兼用接合部・面外補剛）

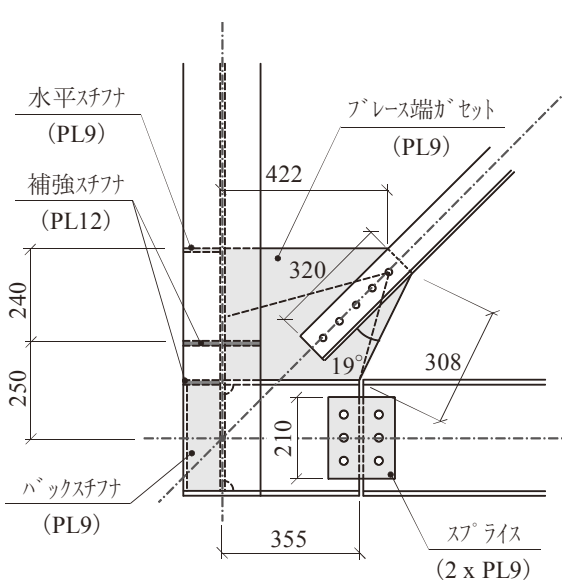

(7) 試験体 $d-1$ (柱梁両溶接)

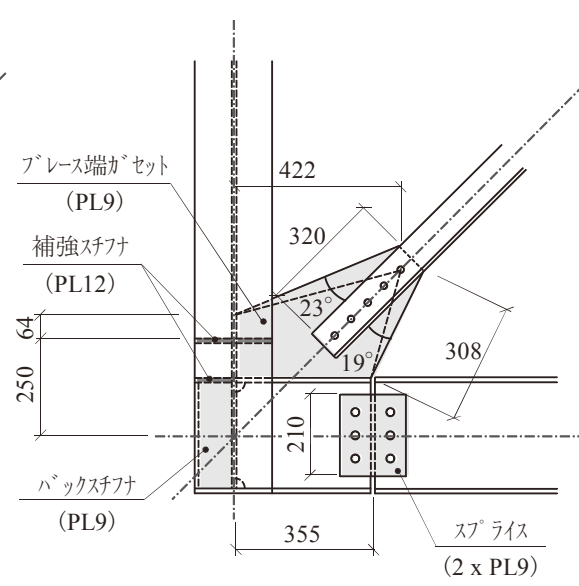

(8) 試験体 $d-1 C$ (柱梁両溶接・柱側最低限)

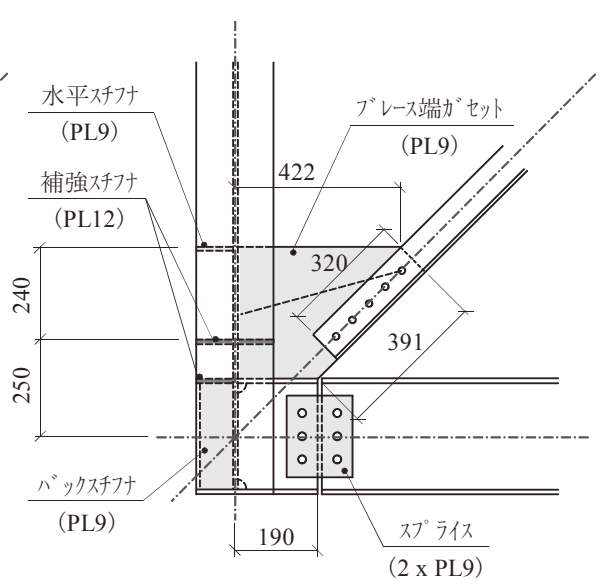

(9) 試験体 d-2（柱梁両溶接・梁側カット）

図 5 試験体（接合ディテール）－覧 


\section{3 試験体}

実験パラメータは, 柱, 梁, ブレースが集結する接合部のディテー ルである。試験体一覧を表 1 に, 接合部詳細を図 5 に示す. 本実験 で対象とする構造形式では, 以下の条件を満たすように接合部の ディテールを決定するのが一般的である.

(1).ブレースの基線を柱と梁の部材心交点と一致させる (ここでブレース基線とは, 山形断面の図心ではなく,ブレー ス端接合部の高力ボルト取り付け位置を表す)

(2). H形断面柱の応力軽減と施工の容易さから梁端のウェブの みを高力ボルト摩擦接合したピン接合とする

\section{3.1 接合ディテール}

\section{【試験体 a】}

これらの条件を満足し,ブレース端と梁端の接合部(以後, それ ぞれをブレース端ガセット, 梁端ガセット)を分離したディテール が試験体a（図5 (1)) である.両者の接合部を分離してブレースの基 線と柱梁の部材心を一致させようとすると,ブレース端ガセットは 柱から片持ち梁のごとく張り出すことになる (以後, 片持ちガセッ ト). なお, 全試験体に共通して, 直交方向に柱と同断面の梁を想 定し, 柱梁接合部に補強スチフナ(PL-12) を設置する.また, ガセッ トプレートの取り付けは, ブレース端と梁端ともに脚長 $6 \mathrm{~mm} の$ 隅 肉溶接を基本とする.

\section{【試験体群 b】}

この試験体 $\mathrm{a}$ に対して,ブレースの基線を偏心させ,ブレース端 ガセットの有効断面と溶接部の有効長を確保したディテールが試験 体群 b（図 5(2)，(3)) である. 梁端の接合条件の違いは, ブレース 軸力と梁軸力によって生じる偏心曲げモーメントに対して, 梁端を ピン接合とした試験体 b-1 では柱により, 梁端を剛接合とした試験 体 b-2では柱と梁により抵抗させることを意図したものである.

\section{【試験体群 c】}

一方，(1)，(2)の条件を満足するため，1枚のガセットプレートに よってブレース端と梁端の接合部を兼ね, 応力伝達を円滑にさせる ことを意図したディテールが試験体群 c（図5(4)～(6))である.な お, ガセットプレートとの接触を避けるため, 梁は材端部で片側フ ランジを切り欠いている.この試験体群ではガセットプレートの形 状を変化させた試験体 c-1 と c-2 に加え, 面外剛性を確保するため の補剛板を設置した試験体 c-1R を用意した.

\section{【試験体群 d】}

さらに, 梁端の接合位置をスパン中央方向にずらし, 剛接合した 柱と梁にブレース端ガセットを溶接にて取り付けたディテールが試 験体群 $\mathrm{d}$ (図5(7) 〜 (9)) である.この試験体群では, 基本的に試験 体群 $\mathrm{c}$ と対応するようにガセットプレートの形状を変化させた.

\section{3. 2 試験体(接合ディテール)の位置づけ}

以上, 全9種類の引張ブレース付き柱梁部分架構を用意し, 接合 ディテールの違いが部分架構の力学挙動に及ぼす影響を考察する. 試験体群 $\mathrm{a} \sim \mathrm{c}$ は図1に示したように実際に用いられる接合ディテー ルを模した試験体である.これに対して, 試験体群 $\mathrm{d}$ は条件 (1), (2) を満足するよう溶接箇所を増やして丁寧に接合部を製作しており, 実際にはあまり見られないディテールである.試験体群dを採用し た理由は, 試験体d-1において接合部耐力を十分に確保し, これを 本実験での基準試験体と位置づけるためである.一方, その他の試
表2 使用鋼材の材料試験結果

\begin{tabular}{|c|c|c|c|c|c|c|}
\hline \multicolumn{2}{|c|}{ 鋼種・板厚 $[\mathrm{mm}]$} & $\begin{array}{l}\text { 降伏点 } \\
{\left[\mathrm{N} / \mathrm{mm}^{2}\right]}\end{array}$ & $\begin{array}{l}\text { 引張強さ } \\
{\left[\mathrm{N} / \mathrm{mm}^{2}\right]}\end{array}$ & $\begin{array}{c}\text { 降伏比 } \\
{[\%]}\end{array}$ & $\begin{array}{c}\text { 破断伸び } \\
\text { [\%] }\end{array}$ & 使用部位 \\
\hline SS400 & 7 & 318 & 442 & 72 & 29 & ブレースL90x90×7 \\
\hline SS400 & 9 & 263 & 410 & 64 & 34 & RH300x150梁フランジ \\
\hline SS 400 & 6.5 & 332 & 435 & 76 & 26 & RH300x150梁ウェブ \\
\hline SM490A & 13 & 345 & 526 & 66 & 26 & RH400x200柱フランジ \\
\hline SM490A & 8 & 379 & 526 & 72 & 25 & RH400x200柱ウェブ \\
\hline SS400 & 9 & 266 & 440 & 60 & 32 & $\begin{array}{l}\text { ガセットプレート } \\
\text { 水平スチフナ } \\
\text { バックスチフナ } \\
\text { BH300x150梁ウェプ }\end{array}$ \\
\hline SS 400 & 12 & 264 & 411 & 64 & 31 & $\begin{array}{l}\text { 補強スチフナ } \\
\text { BH300x150梁フランジ }\end{array}$ \\
\hline
\end{tabular}

表3 ブレース耐カと接合部耐カの計算值 (ブレース軸方向成分)

\begin{tabular}{|c|c|c|c|c|c|}
\hline & \multirow{2}{*}{ 試験体 } & \multirow{2}{*}{$\begin{array}{l}\text { ブレースの軸部 } \\
\text { 降伏耐力 }[\mathrm{kN}]\end{array}$} & \multicolumn{3}{|c|}{ 接合部の破断耐力 $[\mathrm{kN}]$} \\
\hline & & & 梁端高力ボルト※ & ガセッ有効断面 & ガセッ隅肉溶接部 \\
\hline a & a & 777 & 889 & 675 & 673 \\
\hline \multirow{2}{*}{ b } & $b-1$ & 777 & 832 & 787 & 1092 \\
\hline & b-2 & 777 & - & 787 & 1092 \\
\hline \multirow{3}{*}{ c } & $c-1$ & 777 & 889 & 1025 & - \\
\hline & $\mathrm{c}-1 \mathrm{R}$ & 777 & 889 & 1025 & - \\
\hline & c-2 & 777 & 889 & 655 & - \\
\hline \multirow{3}{*}{ d } & d-1 & 777 & 1791 & 1025 & 1410 \\
\hline & $\mathrm{d}-1 \mathrm{C}$ & 777 & 1791 & 1025 & 1410 \\
\hline & $\mathrm{d}-2$ & 777 & 1791 & 655 & 958 \\
\hline
\end{tabular}

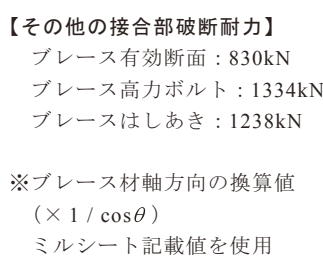

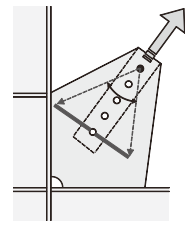

ガセット有効断面”

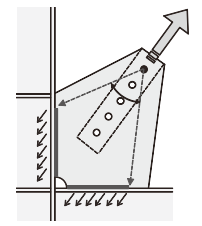

溶接有効領域 ${ }^{11}$ ) 表4＼cjkstart実験結果のまとめ

\begin{tabular}{|c|c|c|c|c|c|c|}
\hline & \multirow[b]{2}{*}{ 試験体 } & \multirow{2}{*}{$\begin{array}{c}\text { 最終破壞状況 } \\
\text { (破断箇・起点) }\end{array}$} & \multicolumn{2}{|c|}{ 架構全体 $\left(Q_{\mathrm{B}}+Q_{\mathrm{F}}\right)$} & \multicolumn{2}{|c|}{ ブレース負担 $\left(Q_{\mathrm{B}}\right)$} \\
\hline & & & $\begin{array}{c}\text { 弾性剛性 } \\
\text { [kN/rad.] }\end{array}$ & $\begin{array}{c}\text { 最大耐力 } \\
{[\mathrm{kN}]}\end{array}$ & $\begin{array}{c}\text { 弾性剛性 } \\
\text { [kN/rad.] }\end{array}$ & $\begin{array}{c}\text { 最大耐力 } \\
{[\mathrm{kN}]}\end{array}$ \\
\hline a & a & 下部溶接先端部 & 99,200 & 200 & 98,000 & 200 \\
\hline \multirow{2}{*}{$\mathrm{b}$} & b-1 & 下部溶接先端部 & 75,400 & 380 & 82,300 & 440 \\
\hline & $\mathrm{b}-2$ & ガセット有効断面 & 99,400 & 530 & 101,800 & 530 \\
\hline \multirow{3}{*}{$\mathrm{c}$} & $\mathrm{c}-1$ & - & 148,300 & - & 146,800 & - \\
\hline & $c-1 R$ & ブレース材中央 & 156,200 & 550 & 154,100 & 540 \\
\hline & $c-2$ & - & 161,800 & - & 159,100 & - \\
\hline \multirow{3}{*}{ d } & d-1 & ブレース材中央 & 157,900 & 560 & 156,500 & 540 \\
\hline & $\mathrm{d}-1 \mathrm{C}$ & ブレース材中央 & 141,000 & 560 & 137,200 & 550 \\
\hline & $\mathrm{d}-2$ & 下部溶接先端部 & 141,600 & 360 & 139,200 & 360 \\
\hline
\end{tabular}

験体では意図的にブレースの軸部降伏耐力を接合部の破断耐力に近 づけ,一部の試験体では接合部の破断が先行するようにブレース断 面を選定した.これらの結果から, 接合部の最大耐力や破壊状況を 把握し, 接合部設計の発展に資する基礎データを得る。

試験体に使用した鋼材のJIS-1A号試験片による材料試験結果を表 2 に示し,材料試験結果に基づいて計算した接合部耐力11)を表3に まとめる.なお, 表中ではブレースの軸部降伏耐力と接合部の破断 耐力を比較し,小さい方, 寸なわち試験体の耐力を決定付ける箇所 を網掛けしている.このうち, 隅肉溶接の破断耐力については, 最 外縁のボルトから片側 $30^{\circ}$ の応力伝達を仮定して有効領域 (溶接始 終端を含む)を定め, 斜方隅肉溶接により耐力を算定している. 


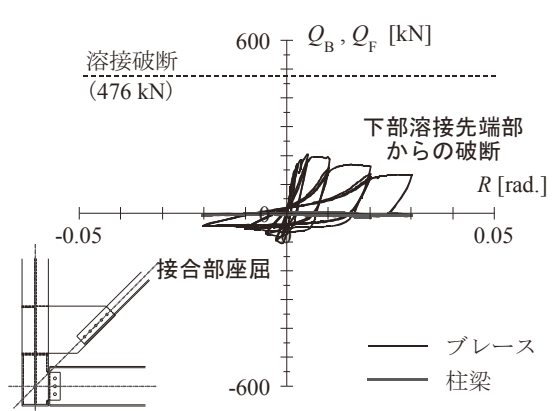

(1) 試験体a（片持ちガセット)

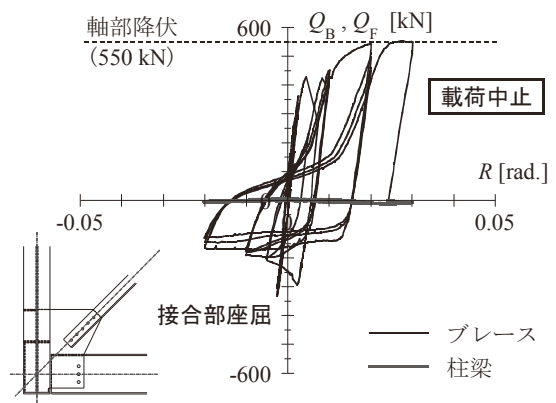

(4) 試験体 c-1（兼用接合部）

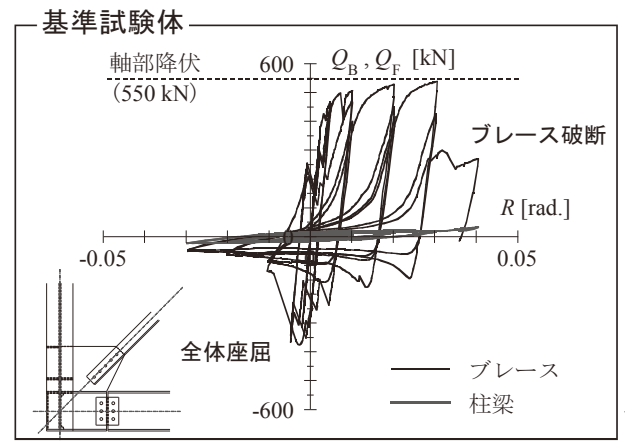

(7) 試験体 $d-1$ （柱梁両溶接）

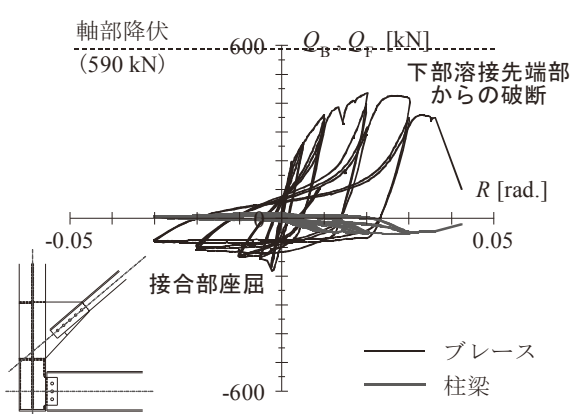

(2) 試験体 b-1（偏心・梁端ピン）

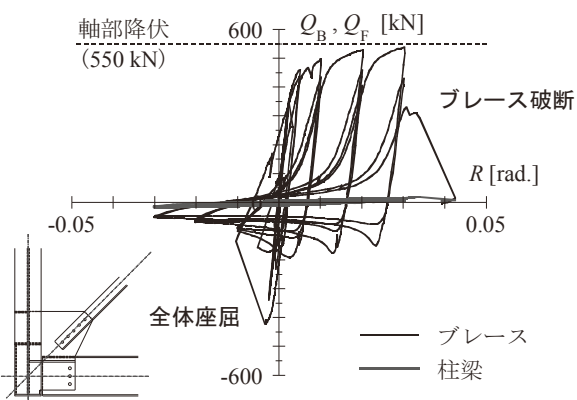

(5) 試験体 c-1R（兼用接合部・面外補剛）

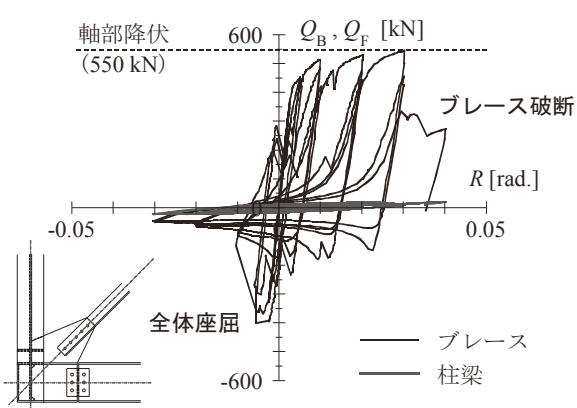

(8) 試験体 d-1C（柱梁両溶接・柱側最低限）

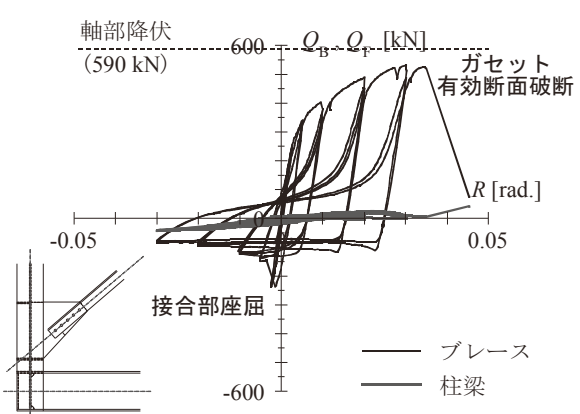

(3) 試験体 b-2（偏心 ・梁端剛）

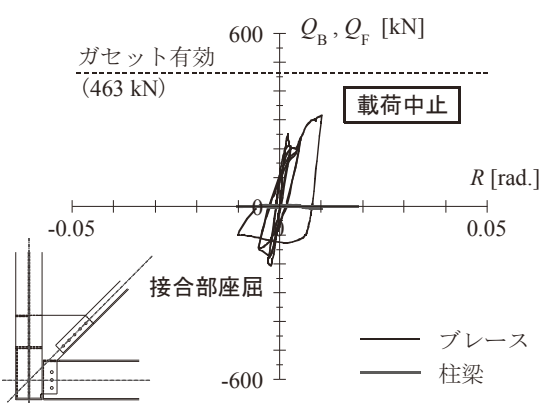

(6) 試験体 c-2（兼用接合部・梁側カット）

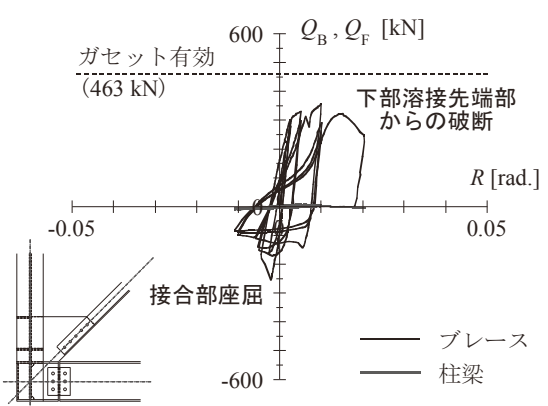

(9) 試験体 d-2（柱梁両溶接・梁側カット）

図6 ブレース付き部分架構の履歴挙動（縱軸: ブレースの負担水平カ, 柱梁架構の負担水平カ)

\section{4 載荷計画}

載荷プログラムには，層間変形角 $\pm 1 / 400(2), \pm 1 / 200(2), \pm$ $1 / 100$ (3) , $\pm 1 / 50$ (3) , $\pm 1 / 33 \mathrm{rad}$. (2) を各振幅で複数回繰り返す漸 増変位振幅載荷を採用し, 最終的には+1/25rad.まで変形させた.文 中の振幅に添えた括弧内の数字が, 各振幅の繰り返し回数である. 載荷はブレースが引張抵抗する側から開始し,その変形を与える載 荷を正方向と定義する.なお, 載荷中に大きな亀裂や破断が生じた 試験体では, 十分な耐力低下が確認できた時点で載荷を終了した。

\section{3. 実験結果と考察}

\section{1 部分架構の履歴挙動と破壊状況 \\ 3. 1.1 実験経過と破壊の分類}

実験より得られた部分架構の履歴挙動として,ブレースの負担水 平力 $Q_{\mathrm{B}}$, 柱梁架構の負担水平力 $Q_{\mathrm{F}}$ を, 層間変形角 $R$ との関係とし て図6にそれぞれ示し, 実験結果を表 4 にまとめる. また, 載荷中 や載荷終了後に観察されたブレースと接合部の破壊状況を図7～図 9に示す. 履歴挙動には正負それぞれの破壊要因を記し, 表3の耐 力を水平成分に置換して破線にて示している.

いずれの試験体も負載荷時にブレースが座屈し, スリップ挙動を 示している.ブレース端ガセットを柱梁に溶接した基準試験体d-1, および試験体d-1C, ガセットプレートに面外補剛を施した兼用接合 部の試験体 c-1R では, ブレースの全体座屈が生じ, 最終的にはブ レース材中央部に破断が生じることで耐力を喪失した(図7). 基準 試験体を含むこれらの試験体では, 軸部降伏が確認されている。

これに対して, その他の試験体では, 図8に示すようにブレース 母材である山形鋼がほぼ原形を留めたままガセットプレートのみが 大きく面外に曲がる座屈 (以後, 接合部座屈) が生じた.さらに, 柱 側のみにガセットプレートを溶接した試験体 $\mathrm{a}, \mathrm{b}-1, \mathrm{~b}-2$ ，および ガセットプレートの梁側を極端に小さくして柱梁に溶接した試験体 d-2では, 最終的には接合部で亀裂が大きく進展し, 急激に耐力を 喪失した (図9). 以降, 本研究では急激な耐力の喪失に至った亀裂 の進展を破断と呼ぶ.一方,ブレース端と梁端の兼用接合部を有し， 面外補剛のない試験体c-1, c-2では, ガセットプレートが梁を引き 連れながら構面外に大きく変形したため, 載荷装置を保護するため に途中で載荷を中止した. 以下, それぞれの破壊状況を詳述する.

\subsection{2 ブレースの全体座屈と破断 (図7)}

本実験で用いた背合わせの $2 丁$ 使いの山形鋼では,ブレース端の 高力ボルト接合部の構面内への回転剛性が高いため, ガセットプ 

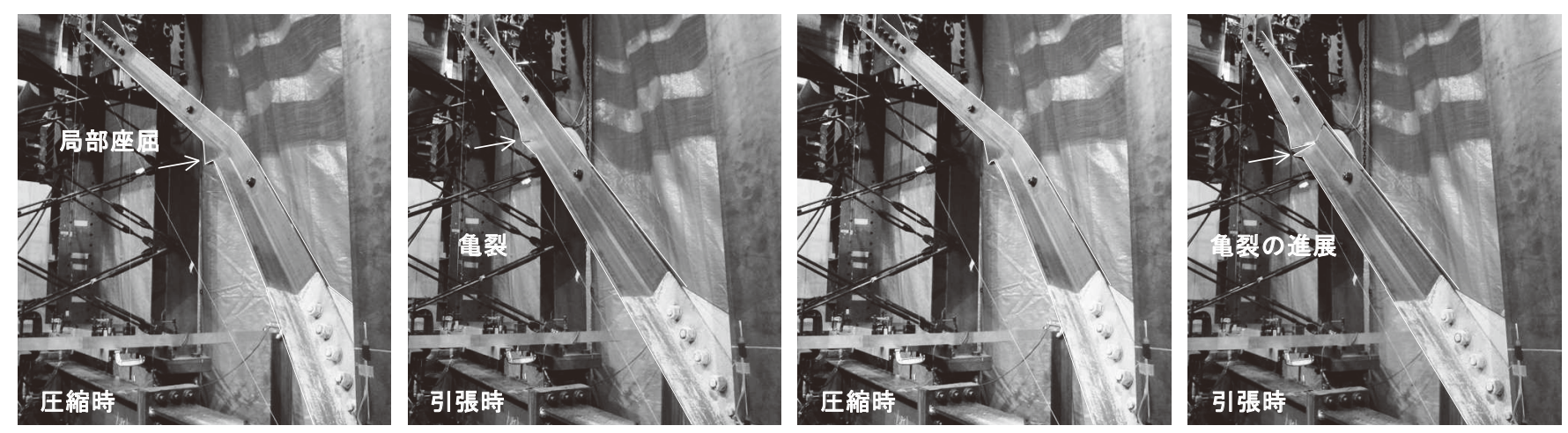

図7 ブレースの全体座屈と繰り返し変形に伴う亀裂の進展 (試験体 $d-1 \mathrm{C}$ (試験体 $d-1$, 試験体 $c-1 R$ も同様) )

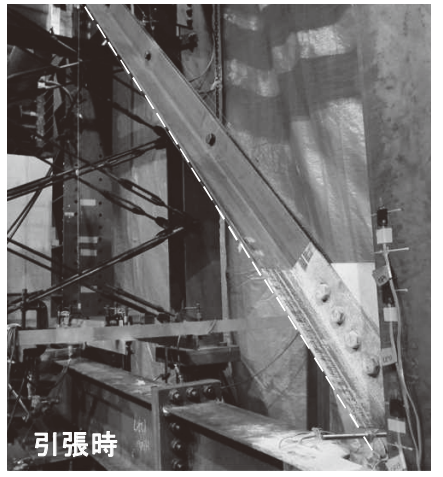

ブレース全体の変形状況 (試験体c-1)

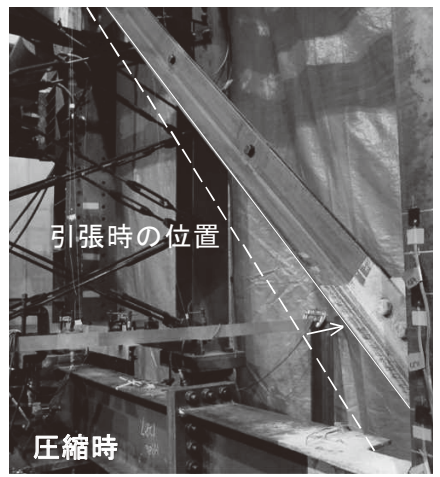

図8 接合部座屈(ブレースは原形を留めたまま, 接合部を起点として生じた座屈)

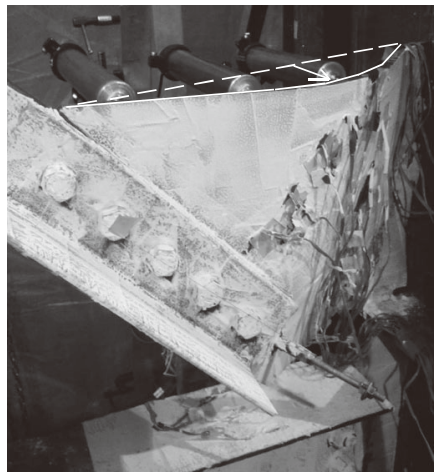

接合部の状況 (試験体a)

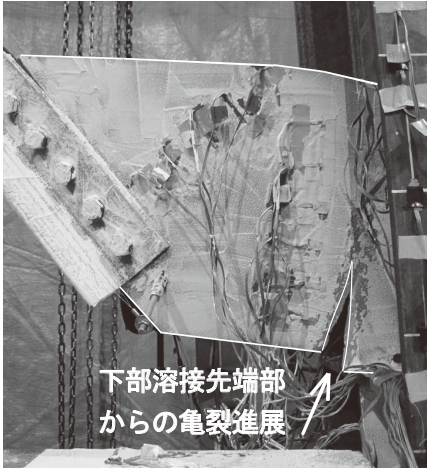

（1）試験体 $\mathrm{a}$

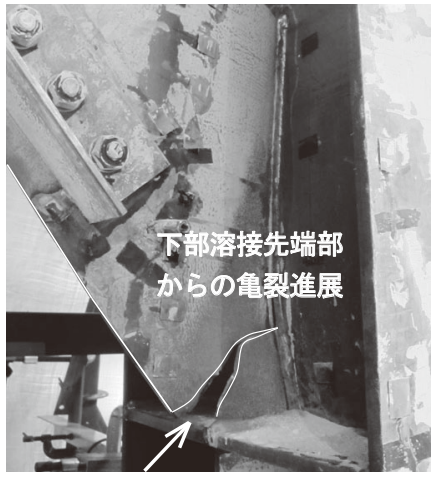

（2）試験体 b-1

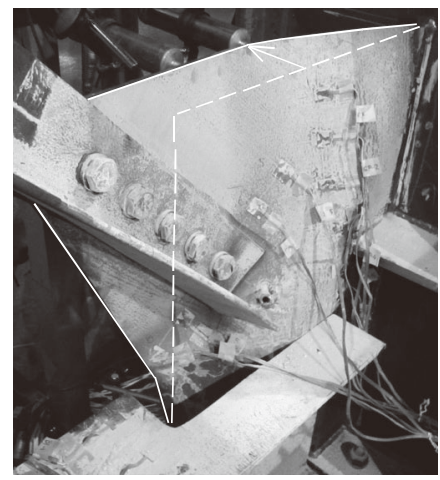

接合部の状況 (試験体c-1)

図9 ブレース端ガセットの下端溶接先端部あるいは有効断面において観察された破断形式

レートの回転剛性が低い構面外への座屈が生じる.また,この場合, 全体座屈によって材中央部に局部座屈が生じ,その部位に現れた亀 裂が繰り返し変形に伴って進展して破断に至るため, 単一山形鋼に 比べて塑性変形性能が低下寸る ${ }^{12)}$.さらに文献 12)，13）の実験を 総合すると, 背合わせの $2 丁$ 使いの山形鋼では, 保有耐力接合され ていても, 繰り返し変形に伴う局部座屈の影響によって必ずしも軸 部降伏耐力を発揮できていないことが分かる.

本実験においても, 全体座屈したブレースは繰り返し変形に伴っ て亀裂が進展して破断に至っており, いずれも $+1 / 25 \mathrm{rad}$. 載荷時に 耐力を喪失している.さらに, 引張側の最大耐力は, 軸部降伏耐力 の 98〜 100\%であり, 計算值に僅かに達していない試験体もある. この原因には材中央部の局部座屈 ${ }^{12}$, つづり部での孔欠損の影響が 考えられる.しかし, 本実験では設計時に想定するブレース材中央

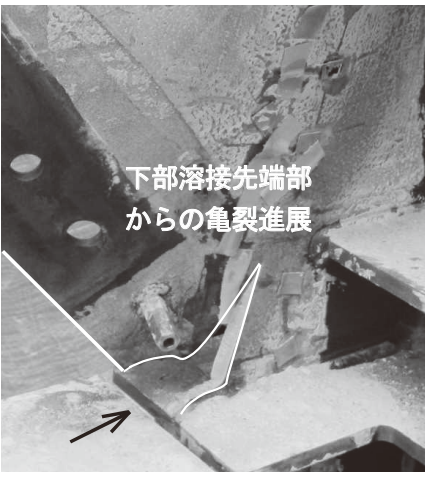

（3）試験体 $\mathrm{d}-2$

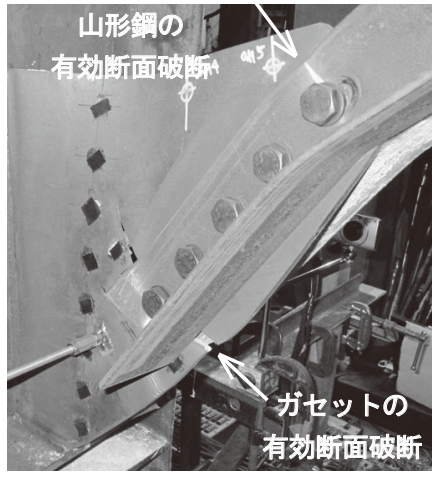

（4）試験体 b-2
部が屈曲する全体座屈が生じていること, 繰り返し変形時にも軸部 降伏耐力の $98 \%$ 以上の耐力を発揮していることから, 基準試験体 $\mathrm{d}-$ 1 およびd-1C, c-1Rは, ブレースの性能を発揮できたと判断する.

\section{1.3 接合部座屈 (図8)}

接合部座屈については, 兼用接合部を含めてガセットプレートが 柱側のみに溶接された試験体, あるいは梁側への溶接長が極端に小 さな試験体で発生した.ブレースの全体座屈に比べると座屈耐力は 低い傾向にあるが, 兼用接合部の試験体 $\mathrm{c}-1, \mathrm{c}-2$ では, 座屈後の安 定耐力は全体座屈に比べて高いことが分かる.また, 載荷を進めた 試験体c-1では軸部降伏耐力の計算值を超えた付近で耐力が頭打ち となる明確な軸部降伏が確認できる.これは接合部を起点とした座 屈ではブレースが原形を保ったままであり, 3.1.2で述べたような材 中央部での局部座屈や亀裂が発生しなかったためである.しかし, 


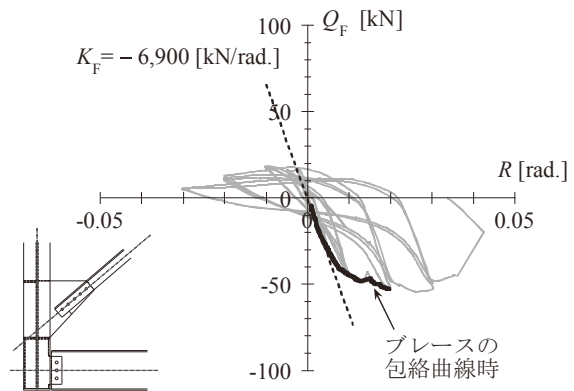

(1) 試験体 b-1（偏心・梁端ピン）

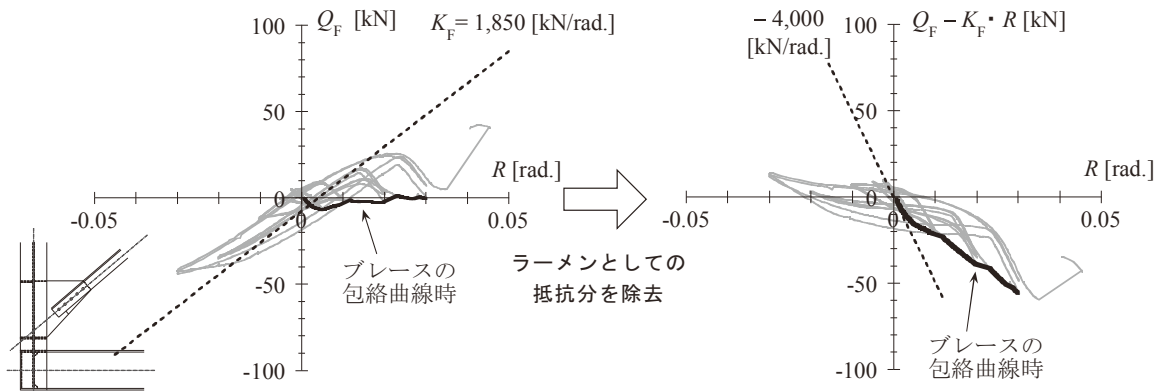

(2) 試験体 b-2（偏心・梁端剛）

図10柱梁架構の履歴挙動(偏心ありの試験体, 図6の縦軸を拡大)

これらの結果は, 梁自由端位置において構面外変位と回転が水平反 力治具により拘束されている条件で得られたものである.兼用接合 部ではガセットプレートの面外変形が梁を引き連れて生じており, 梁の材中央が小梁などによって面外変位を拘束されていない場合に は, 梁の面外座屈が引き起こされ, 梁が十分に軸力を伝達できない 可能性がある.

一方, 本実験では, 梁の材端部で切り欠いたフランジ幅程度の補 剛板(ただし柱断面内では幅を広げて全周を隅肉溶接)をガセットプ レートに取り付けた試験体c-1Rにおいて, 接合部座屈を回避し,ブ レースの全体座屈に至らしめることに成功している.このことか ら, ガセットプレートに適切な面外補剛を施せば, 兼用接合部にお いてもブレースの性能を十分発揮できると言える.

\subsection{4 接合部破断（図9)}

接合部座屈が発生した試験体のうち, 幾つかの試験体では, 最終 的に接合部破断に至っている.また, これらの試験体ではブレース 端ガセットの下端溶接先端部に+1/100〜+1/50 rad. 時に亀裂が確認 されている。この溶接部は, 試験体 $\mathrm{a}, \mathrm{b}-1, \mathrm{~b}-2$ では補強スチフナ との接合部分, 試験体d-2では梁フランジとの接合部分である.

試験体 $\mathrm{a}, \mathrm{b}-1, \mathrm{~d}-2$ ではこの下端溶接先端部の亀裂が繰り返し変 形に伴ってガセットプレートへと進展し, 破断に至った(図9(1)〜

(3)) . スリップ挙動を呈する正載荷時の引張軸力はさほど大きくな いにもかかわらず, 同一変位振幅の繰り返し変形においても亀裂が 進展しており,破断にはガセットプレートの面外曲げ変形に伴う負 荷も影響していると考えられる。

これに対して, 試験体 b-2 は, ブレース端ガセットの有効断面破 断によって急激に耐力を喪失し, 載荷後には山形鋼の有効断面にも 亀裂が確認された(図9 (4)). 試験体b-2のブレース端ガセットの下 端溶接部は, 試験体b-1 と同様に補強スチフナに接続するが, その さらに下部に梁端ガセットが接続していない点のみが異なる.この ことから, 溶接先端部における応力集中が補強スチフナの面外変形 によって緩和されたなど, 接合部ディテールのわずかな違いが接合 部の最大耐力や破壊状況に影響したものと推察される.

\subsection{5 接合部破断に至った試験体の最大耐力と設計時の計算}

試験体 $\mathrm{a}, \mathrm{d}-2$ は，接合部の破断耐力がブレースの軸部降伏耐力よ り下回る試験体であるが，実験では計算值より低い荷重 $(42 \%$, $78 \%)$ でブレース端ガセットの下端溶接先端部の亀裂を起点とする破 断に至った。この結果は, 仮にブレース断面を小さくして設計時の 計算(表3)にて軸部降伏が接合部破断に先行するよう設計しても, 接合部の破断が先行する可能性があることを表す.また,ブレース の軸部降伏耐力と接合部の破断耐力がほぼ等しい試験体b-1, b-2 に ついても,ブレースの軸部降伏には至らずに接合部が破断し, 最大 耐力は計算值より低い荷重 $(75 \%, 90 \%)$ であった。この結果には設 計時の計算 (表3)が不十分であること,接合部係数に相当する安全 率が確保されていたかということが関係する.破断耐力の計算につ いては, 試験体b-2ではブレース端ガセットの有効断面がブレース 基線に対して非対称であったこと, 他の試験体ではブレース端ガ セットに対して柱側にバックスチフナを取り付けていないことが, それぞれの耐力低下に影響を及ぼしたと考えられる。

\section{2 部分架構の弾性剛性 \\ 3.2. 1 実験結果の概要}

本節では, 実験より得られた部分架構の弾性剛性について考察す る. 表4中の弾性剛性をみると, 偏心を有する試験体b-1を除き, 架 構全体とブレース負担のみの弾性剛性はほぼ等しく,柱梁架構の負 担は僅かである。一方, 偏心を有する試験体 b-1, b-2では, 載荷初 期には柱梁架構の履歴が第4象限に現れる逆せん断状態となってお り, 架構全体としてみた方が弾性剛性が低い. 柱梁架構の履歴挙動 （図6）を, 縦軸を拡大して図10に示す. 試験体b-2 はラーメンとし ての抵抗を有寸るが, その影響を除去した右端の図からブレースが 弾性の範囲では逆せん断の影響が強いことが分かる.

ここでブレースである山形鋼の材長 (節点間) と断面積により決ま る軸剛性に基づいて水平剛性を計算すると, 部分架構の水平剛性は 239,000 (169,000) kN/rad. となる. 実験より得られた試験体群 c, d の弾性剛性は,材長を節点間距離とした計算值より 5 20\%程度低 い結果となっている。一方, 片持ちガセットの試験体 $\mathrm{a}$, 偏心を有 する試験体群 $\mathrm{b}$ では, 計算值の $40 \sim 52 \%$ 程度の剛性しか発揮でき ていない.これにはブレースを偏心させたことによる幾何学的な条 件の変化に加え, 柱の曲げ変形に伴うブレース取り付け位置での水 平変位が影響していると考えられる。

\section{2.2 ブレースの偏心による影響の評価}

ここでは, 偏心を有するブレース付き部分架構の剛性評価モデル を図11のように考え, 評価を行う.偏心がない部分架構において節 点間を材長としたブレースの軸剛性 $k_{\mathrm{B}}[\mathrm{kN} / \mathrm{mm}]$ に対して, 偏心に伴 う幾何学的な条件の変化により, 部分架構の水平剛性 $K_{\mathrm{B}}[\mathrm{kN} / \mathrm{rad}$. $]$ は変化する.すなわち, ブレース材長, 取り付け角度, およびブレー ス水平変位のそれぞれが減少し,これら幾何学的な条件の変化を考 慮したブレース付き部分架構の水平剛性 $K_{\mathrm{B}}$ は次式で表せる.ここ で偏心距離 $e$ は, 柱梁の部材心交点から,ブレースの基線と柱部材 心の交点までの距離 $(=300 \mathrm{~mm})$ とする. 


$$
K_{\mathrm{B}}=k_{\mathrm{B}} \cdot H \cdot \sqrt{\frac{L^{2}+H^{2}}{L^{2}+(H-e)^{2}}} \cdot \frac{L^{2}}{L^{2}+(H-e)^{2}} \cdot \frac{H-e}{H}
$$

これに加え, ブレースの負担水平力は, 取り付け位置から柱の曲 げ変形を介して柱梁架構に伝達するため,ブレース取り付け位置に 水平変位 $\Delta_{\mathrm{c}}$ が生じる.この水平変位は, ブレースの負担水平力 $Q_{\mathrm{B}}$ に依存する。

$$
Q_{\mathrm{B}}=K_{\mathrm{c}} \cdot \Delta_{\mathrm{c}} \quad \cdots(2)
$$

以上より, 偏心を有するブレース付き部分架構の水平剛性 $K_{\mathrm{B}}{ }^{*}$ は, (1)式と (2) 式を直列結合した次式によって表せる.

$$
K_{\mathrm{B}}^{*}=\left(\frac{1}{K_{\mathrm{B}}}+\frac{1}{K_{\mathrm{c}}}\right)^{-1} \quad \cdots(3)
$$

柱梁を線材にモデル化した数值解析より水平剛性 $K_{\mathrm{c}}$ を算出し, 幾 何学的な条件の変化を含めて算出した剛性 $K_{\mathrm{B}}{ }^{*}$ を表 5 に示す.なお, 梁端を剛接合とした場合, 柱のたわみによって $\Delta_{\mathrm{g}}$ は図11(a)より 小さくなるが,ここではその影響は考慮していない. 計算值は, 両 試験体の実験值(表4) とほぼ一致しており, 剛性低下の影響を十分 に評価できている．したがって, 偏心を有するブレース付き部分架 構の水平剛性は, 柱の曲げ変形に伴うブレース取り付け位置での水 平変位を考慮することが重要であると言える.

\section{3 部分架構の最大耐力}

\section{3.1 片持ちガセットの耐カ評価}

ここでは引き続き, 接合部破断によってブレースの性能を発揮で きなかった試験体に対して, 最大耐力の低下要因を検討する.まず, 片持ちガセットを有する試験体 $\mathrm{a}$ を対象とする.片持ちガセットは ブレース軸力を柱に伝達する役割を担うが, 実験では載荷方向によ らず面外変形が生じ,ブレースの引張時抵抗が損なわれた。

片持ちガセットの応力評価モデルを図 12 (a) に示す．片持ちガ セットの断面には, ブレース軸力の鉛直成分 $Q_{\mathrm{B}} \tan \theta$ がせん断力と して曲げモーメント $M_{\mathrm{g}}$ を生じさせるとともに, 負担水平力 $Q_{\mathrm{B}}$ が軸 方向力として作用する ( $\theta$ は取付角度).いま, 片持ちガセットの部 材心とブレースの基線が交差する点を片持ち梁の自由端とすれば, 自由端から $l_{\mathrm{g}}$ 離れた位置の $N-M$ 関係を容易に得ることができる. このモデルの妥当性を検証するため, 実験において $l_{\mathrm{g}}=304 \mathrm{~mm} の$ 断面に $50 \mathrm{~mm}$ ピッチで表裏に計12枚貼付したひずみゲージより得 た $N-M$ 関係を, 応力評価モデルによる計算值, 片持ちガセット断 面の曲げ耐力相関曲線と併せて図12 (b) に示す. 実験結果と計算值 は極めてよく対応しており,ここで示した片持ちガセットの応力評 価モデルは妥当であると言える.

以上の検証を踏まえ, 応力評価モデルに基づいた片持ちガセット の耐力を考える.片持ちガセットは矩形断面 (せい $d_{\mathrm{g}} \times$ 幅 $t_{\mathrm{g}}$ ) であ るため, 使用鋼材の降伏応力度を $\sigma_{\mathrm{y}}$ とおけば, 危険断面位置が軸 力を考慮した降伏モーメント $M_{\mathrm{yc}}$ と全塑性モーメント $M_{\mathrm{pc}}$ のそれぞ れに到達する際のブレースの負担水平力 $Q_{\mathrm{B}}$ は, 次式で表せる.

$$
\begin{aligned}
& Q_{\mathrm{B}\left(M=M_{\mathrm{yc}}\right)}=\frac{t_{\mathrm{g}} d_{\mathrm{g}}{ }^{2} \sigma_{\mathrm{y}}}{\left(6 l_{\mathrm{g}}+d_{\mathrm{g}}\right) \tan \theta} \\
& Q_{\mathrm{B}\left(M=M_{\mathrm{pc}}\right)}=-2 t_{\mathrm{g}} l_{\mathrm{g}} \sigma_{\mathrm{y}} \tan \theta+t_{\mathrm{g}} \sigma_{\mathrm{y}} \sqrt{\left(2 l_{\mathrm{g}} \tan \theta\right)^{2}+d_{\mathrm{g}}{ }^{2}}
\end{aligned}
$$

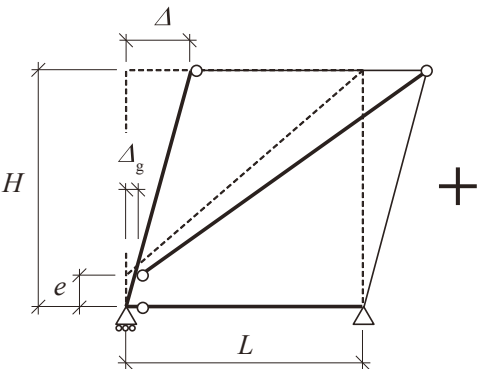

(a) 幾何学的条件により 決まる偏心の影響

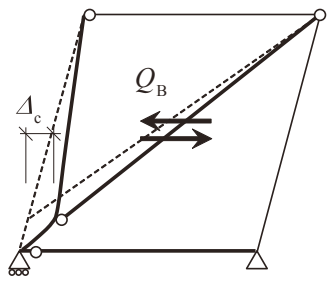

\begin{tabular}{|c|c|c|c|}
\hline & $\begin{array}{c}\text { 幾何学的な影響を } \\
\text { 考慮した水平剛性 } \\
K_{\mathrm{B}}[\mathrm{kN} / \mathrm{rad} .]\end{array}$ & $\begin{array}{c}\text { 柱の曲げ変形に } \\
\text { よる水平剛性 } \\
K_{\mathrm{c}}[\mathrm{kN} / \mathrm{rad} .]\end{array}$ & $\begin{array}{c}\text { 柱の曲げ変形を } \\
\text { 考慮した水平剛性 } \\
K_{\mathrm{c}}{ }^{*}[\mathrm{kN} / \mathrm{rad} .]\end{array}$ \\
\hline b-1 & 179,420 & 135,500 & 77,200 \\
\hline$b-2$ & 179,420 & 299,000 & 112,000 \\
\hline \multicolumn{4}{|c|}{ ※ブレースの材長は, 偏心がない場合に節点間距離 $(=3100 \mathrm{~mm})$ としている } \\
\hline & $\underset{\mathrm{C}}{\rightarrow} K_{\mathrm{c}}=\frac{Q_{\mathrm{B}}}{\Delta_{\mathrm{c}}}$ & モデル & $\begin{array}{l}\text { 梁端 “岡” モデル } \\
\rightarrow K_{\mathrm{c}}=\frac{Q_{\mathrm{B}}}{\Delta_{\mathrm{c}}} \cdot H \\
\rightarrow\end{array}$ \\
\hline
\end{tabular}

(b) ブレース取り付け位置 における水平変位
図11 偏心を有する部分架構における剛性評価モデル

表5＼cjkstart柱の変形を考慮した剛性評価の結果

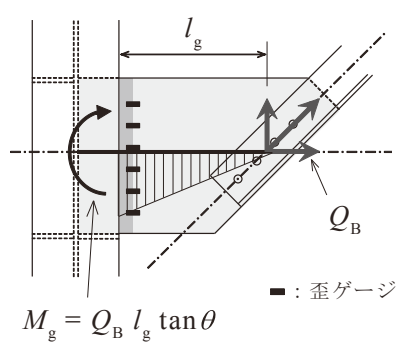

(a) 応力評価モデル

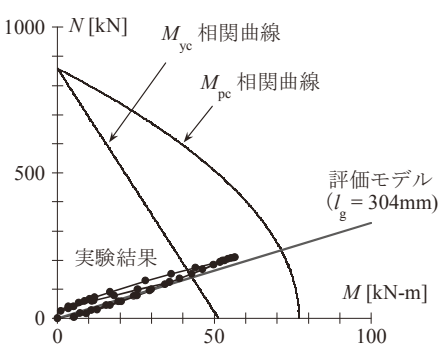

(b) 歪ゲージ貼付位置の挙動
図12 片持ちガセットの応カ評価モデルと検証

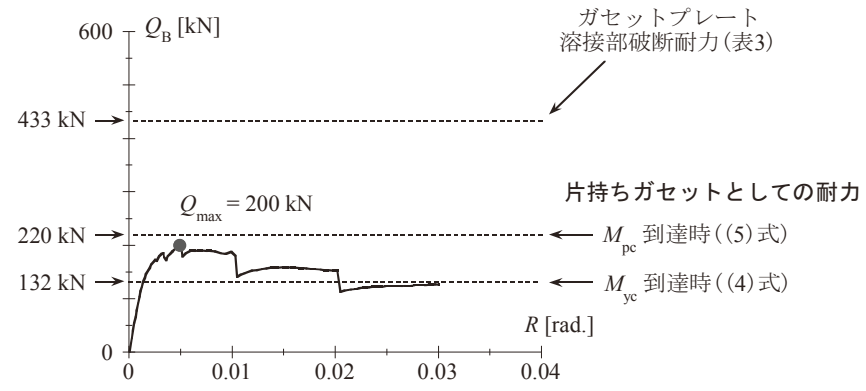

\section{図13＼cjkstart試験体aの包絡曲線と耐カ評価モデルによる計算値}

ここで, 危険断面位置を柱フェイス位置 (図 12 中の $l_{\mathrm{g}}(=329 \mathrm{~mm}$ )) として評価した耐力を, 履歴曲線より得た包絡曲線と併せて図13に 示寸. 実験の履歴曲線では, 危険断面が降伏モーメント $M_{\mathrm{yc}}$ に到達 する時の水平力から非線形化が現れ始めており, 片持ちガセットを 有する部分架構の非線形化の要因をよく説明できている.一方, 実 験における最大耐力は, 危険断面が全塑性モーメント $M_{\mathrm{pc}}$ に到達す る時の水平力に対しておおよそ $90 \%$ 程度であった.これはブレース 


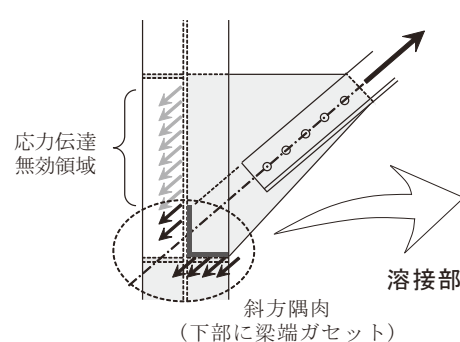

(1) 試験体 b-1

(1) 試駚体 $\mathrm{b}-1$

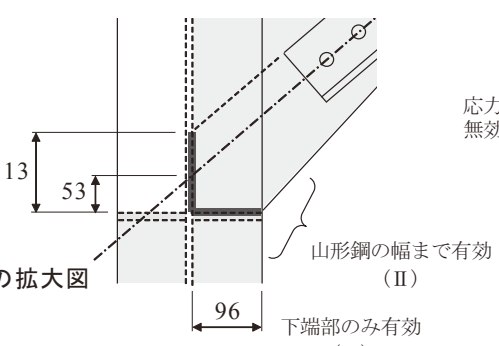

( I )

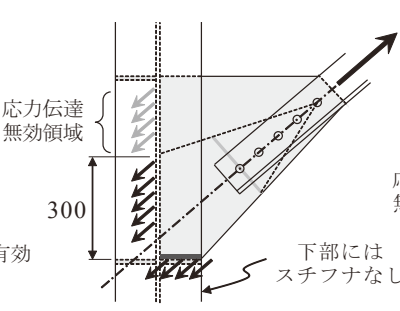

(2) 試験体 b-2

(偏心 ・梁端剛)

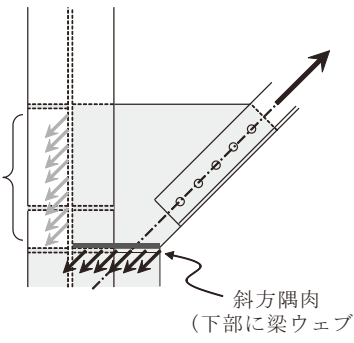

(3) 試験体 $d-2$

図14柱側にバックスチフナがない接合部における溶接部有効領域の仮定

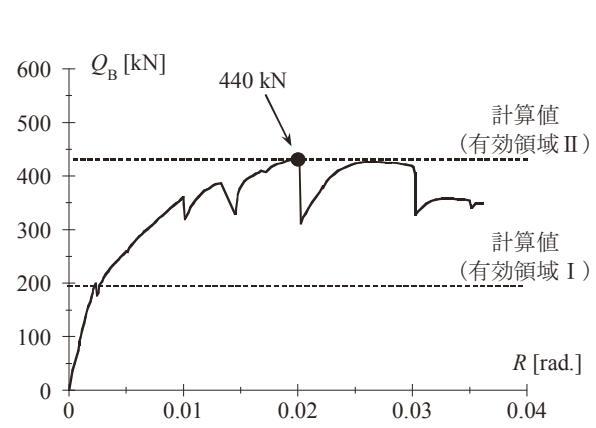

(1) 試験体 b-1（偏心・梁端ピン）

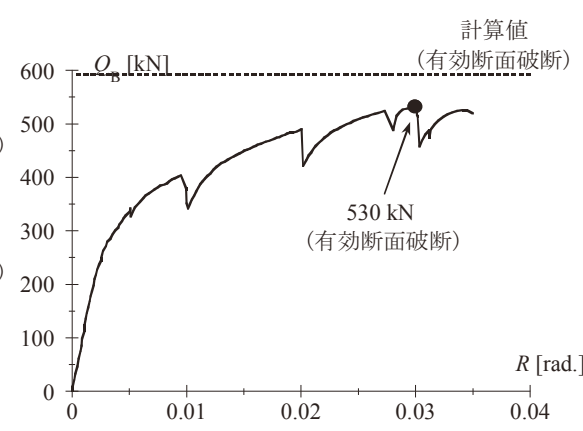

(2) 試験体 b-2（偏心・梁端剛）

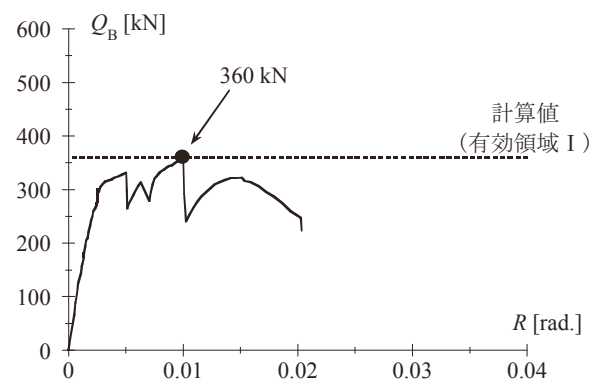

(3) 試験体 d-2（柱梁両溶接・梁側カット）

図15 部分架構の包絡曲線と溶接部の有効領域を再検討した耐力評価結果

の圧縮時には片持ちガセットの危険断面位置が面外に大きく曲げら ること,引張時においても片持ちガセットの曲げ圧縮側では面外変 形が元に戻りにくいことが原因であると考えられる.ガセットプ レートは, 圧縮時にはブレースの座屈に伴う構面外一の回転変形が 要求される部位である.したがって,この部位に付加的な曲げモー メントを含んだブレース軸力の伝達を期待するのは過酷であり, 繰 り返し変形に伴う耐力低下を引き起こす要因になると言える.

\section{3.2 下端溶接先端部を起点とする破断に対する評価法の検討}

最後に, ブレース端ガセットの下端溶接先端部を起点とする接合 部破断に至り,ブレースの性能を発揮できなかった試験体b-1, d-2 に対して, 最大耐力の低下要因とその評価法を検討する.3.1.5で述 べたように, 本実験ではブレース端ガセットに対して柱側にバック スチフナを配していないため,柱ウェブの面外変形が柱側溶接部の 応力伝達能力を低下させ, 下端溶接先端部の亀裂発生とその進展に よる接合部破断を招いたものと推察される.

ここでは, 柱側溶接部の応力伝達の低減を図14のように考えて検 討する.まず, 極端な方法として, 柱側溶接部の応力伝達を完全に 無視し, 下端溶接部のみを有効と寸る評価方法が考えられる(図14 (1)，(3)）。これを有効領域 I とする. 一方, 試験体b-1のようにブ レースの基線が柱側溶接部と交差する場合には, 柱側溶接部の寄与 も考慮することが適切であると考えられる.ここでは仮にブレース に用いた山形鋼の断面幅までを柱側溶接部の有効領域とし, これを 下端溶接部に加えたものを有効領域 II とする(図14(1)) . 以上の仮 定に基づいた溶接部の有効領域を用いた計算結果を表6に示す.ま た, ブレース端ガセットの有効断面破断に至った試験体b-2を含め, 試験体b-1, d-2の履歴曲線より得た包絡曲線と計算結果を併せて図 15 に示す。

ブレース端ガセットを柱梁に溶接した試験体d-2については, 計
表6 ブレース端ガセットの溶接部の有効領域と耐力評価結果

\begin{tabular}{|c|c|c|c|c|c|c|}
\hline & \multirow[b]{2}{*}{ 溶接部の有効領域 } & \multicolumn{2}{|c|}{ 有効溶接長 [mm] } & \multicolumn{2}{|c|}{ 斜方隅肉耐力 $[\mathrm{kN}]$} & \multirow{2}{*}{$\begin{array}{c}\text { 水平耐力 } \\
{[\mathrm{kN}]}\end{array}$} \\
\hline & & 柱側 & $\begin{array}{l}\text { 下端部 } \\
(\text { 梁側) }\end{array}$ & 柱側 & $\begin{array}{l}\text { 下端部 } \\
\text { (梁側) }\end{array}$ & \\
\hline \multirow{2}{*}{$\mathrm{b}-1$} & I：下端部のみ & 0 & 96 & 0 & 259 & 195 \\
\hline & II ：柱側一部を考慮 & 113 & 96 & 313 & 259 & 431 \\
\hline$d-2$ & I：下端部のみ & 0 & 186 & 0 & 509 & 384 \\
\hline
\end{tabular}

算値と実験值はよく対応している.したがって,柱側にバックスチ フナがなく,ブレースの基線が下端溶接部と交差している場合に は, 下端溶接部のみを有効領域とした耐力評価によって, 実験にお ける接合部破断を十分に説明できると言える.

これに対して, 偏心を有する試験体b-1では, 下端溶接部のみを 考慮した有効領域 I により評価した耐力は, 実験より得られた最大 耐力の半分程度以下となっている. しかし, 柱側溶接部の一部を考 慮した有効領域 II による耐力評価では, やや染意的な設定ではある ものの, 計算值と実験值はよく対応している.この検討結果は, ブ レースの基線が柱側溶接部と交差するような場合には, バックスチ フナがなくとも, 柱側溶接部の一部を加えて接合部の最大耐力を評 価できる可能性を示している.

ただし，上記の検討結果は，わずか 2 体の実験結果に対するもの であり,種々の条件を反映できる耐力評価法を構築できた訳ではな い. 本実験の範囲においても, 試験体b-1 とほぼ等しいディテール を有する試験体 b-2では, 試験体b-1 より $20 \%$ ほど高い耐力を発揮 し,ブレース端ガセットの有効断面破断に至っている.これは, 下 端溶接部の下方に梁端ガセットが接続されておらず, 柱側と下端の 溶接部では共に板の面外変形を介した応力伝達となり, 結果として 溶接部の有効領域を広く確保できたためであると考えられる(図14 (2)).このように僅かなディテールの違いが接合部の最大耐力に影 
響を及ぼすため, 追加実験の実施や数值解析による検討をはじめ, 種々のディテールの違いを反映できるブレース端接合部の耐力評価 法の構築が今後の検討課題である.

\section{4. まとめ}

本研究では, 接合ディテールの違いが部分架構の力学挙動に与え る影響を把握するため, 柱梁を含むブレース端の接合ディテールを パラメータとした引張ブレース付き柱梁部分架構の載荷実験を行っ た.以下に得られた結果をまとめる.

[1] ガセットプレートを片持ち梁状に柱に取り付ける場合には,ブ レースの基線と柱梁部材心を一致させても, ガセットプレート に付加的な応力が作用し, 部分架構の耐力が片持ちガセットの 曲げ耐力によって決定付けられることがある.また, 片持ちガ セットは,ブレースの圧縮時に面外に曲げられ, 引張時にも曲 げ圧縮を受けるために面外変形が戻り難いため, 繰り返し変形 下では全塑性曲げ耐力を発揮しにくいことが分かった。

[2] ブレース端と梁端の接合部を兼用したガセットプレートでは, 接合部を起点とする座屈に至り, 接合部における面外変形は梁 を引き連れながら発生した。これは, 本実験の境界条件と異な り, 梁の材中央において小梁などを取り付けずに構面外変位を 拘束していない場合には, 梁が十分に軸力を伝達できない可能 性があることを示している，ただし，本実験ではガセットプ レートに面外補剛を施すことでブレースを全体座屈に至らし め,ブレースの性能を発揮させられる結果も得られた。

[3] ブレースの基線を柱梁部材心から柱側に偏心させた場合, 柱に 付加曲げが作用し, 弾性剛性が低下寸る.このときの弾性剛性 は, 幾何学的な条件の変化, 柱の曲げ変形に伴うブレース取り 付け位置での水平変位を考慮することで評価できる.

[4] 本実験では,ブレース端ガセットに対して柱側にバックスチフ ナを配していないため, 柱側溶接部の応力伝達能力が低下し, 一部の試験体では下端溶接先端部の亀裂を起点とする接合部破 断に至った.この結果に対して,ブレースの基線が下端溶接部 と交差している場合には下端溶接部のみを有効とし, またブ レースの基線が柱側溶接部と交差している場合には柱側溶接部 の一部を有効領域に加えることで, 最大耐力を評価できる可能 性を示した.ただし,これらはわずか 2 体の実験結果に対する 検討であるため, 追加検証が必要である.

この他, 偏心を有する試験体b-1, b-2では, 他の試験体に比べて 履歴曲線の軟化が早期に生じており, 試験体b-1では柱の塑性化が 確認されている.これらには偏心による付加曲げに加え, ブレース 端ガセットの有効断面における降伏耐力が著しく低かったことが影 響していると考えられる.一方, 偏心によって生じる付加曲げにつ いては, 本実験の試験体は $1 / 4$ 構面を切り出した部分架構であり, 柱 の反曲点位置が固定されているため, ブレースの偏心に伴う付加曲 げの分配は必ずしも現実的なものとなっていない.より現実的な境 界条件における引張ブレース付き架構の挙動, 偏心の影響について は検討中であり ${ }^{14)}$, 稿を改めて報告したい.

\section{謝辞}

本研究は平成 23 年度 国土交通省 建築基準整備促進事業「鉄骨 造建築物の基準の整備に資する検討」において行われたものです. また, 同事業にて設置された接合部ディテール調査委員会の皆様に は実験計画に対して貴重なご意見をいただきました.ここに記して 謝意を表します。

\section{参考文献}

1）五十嵐定義, 井上一朗, 木林長仁, 浅野美次 : 筋違付架構の復元力特性, その 1 交番繰返し軸力を受ける筋違材の挙動, 日本建築学会論文報告 集，第 196 号, pp.47-54, 1972.6

2) 加藤 勉, 秋山宏 : 鋼構造筋違付骨組の復元力特性, 日本建築学会論文 報告集，第260 号, pp.99-107, 1977.10

3）柴田道生, 中村 武, 若林 實: 鉄骨筋違の履歴特性の定式化一その 1 定 式化関数の誘導一, 日本建築学会論文報告集, 第316号, pp.18-24, 1982.6

4) 羽倉弘人, 平野道勝, 佐藤 誠, 難波恒夫 : ターンバックル付筋違に関 寸る研究 その $1 \sim 4$, 日本建築学会大会学術講演梗概集, 構造系, pp.485492, 1971.11

5) 田沼吉伸, 加藤 勉, 森田耕次 : 山形鋼筋違接合部の耐力に関する研究, 日本建築学会論文報告集, 第 325 号, pp.32-39, 1983.3

6) 加藤 勉, 田中淳夫, 榎本憲正 : H形鋼軸組筋かい材端接合部に関寸る実 験的研究, 日本建築学会大会学術講演梗概集, 構造系, pp.1317-1318, 1983.9 /同 その2, 日本建築学会大会学術講演梗概集, 構造系, pp.15551556, 1984.10/同 その3, 日本建築学会大会学術講演梗概集, 構造系, pp.947-948, 1985.10

7）難波恒夫, 高橋雅充: ターンバックル付きブレースを有する鉄骨フレー 厶実験, 日本建築学会大会学術講演梗概集, 構造系, pp.1417-1418, 1978.9

8）加藤 勉, 森田耕次, 田沼吉伸, 高橋良明: 筋違付骨組の挙動に与える 筋違接合部の影響に関する実験的研究, 日本建築学会大会学術講演梗概 集, 構造系, pp.1293-1294, 1980.9

9）伊山潤, 山田哲, 松本由香, 吉敷祥一, 小山毅, 島田侑子 : 東北地 方太平洋沖地震等による鉄骨造文教施設鉛直ブレースの震動被害, 日本 建築学会技術報告集, 第 19 巻, 第 41 号, pp.147-152, 2013.2

10）国土交通省住宅局建築指導課：2007年版 建築物の構造関係技術基準解 説書, pp.329-334, 2007.8

11) 日本建築学会：鋼構造接合部設計指針, pp.263-267, 2012.3

12）尾澤 聡, 小澤亮公, 山下哲郎：山形鋼を用いた $X$ 型ブレースの而震性 能に関する実験的研究 その 1,2 , 日本建築学会大会学術講演梗概集, C1 分冊, pp.801-804, 2009.8

13）増田真也, 山下哲郎 : 両端ガセットプレート接合された山形鋼ブレース の座屈耐力に関する実験, 日本建築学会大会学術講演梗概集, C-1 分冊, pp.979-980, 2010.9

14) 吉敷祥一, 深谷佳恵, 巽 信彦, 山田哲, 長谷川隆, 佐藤亮太, 河野由 佳 : 引張ブレース構造に関する研究 その $1 \sim 4$, 日本建築学会大会学術 講演梗概集, C-1 分冊, pp.1175-1182, 2014.9
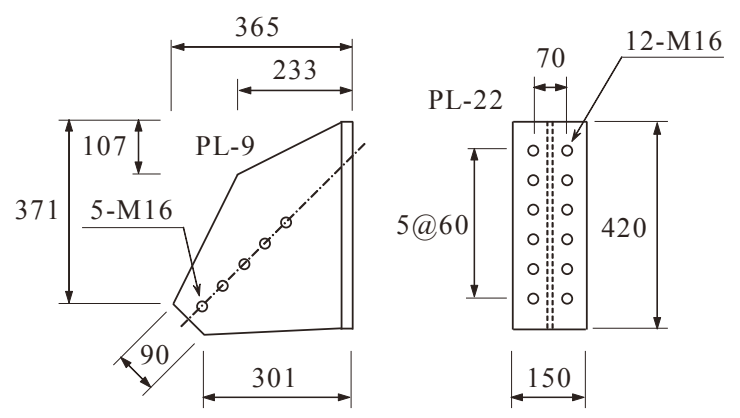

付図1 独立柱側のガセットプレート詳細（試験体群 d 用) 


\title{
EFFECTS OF DIFFERENCES IN CONNECTION DETAILS \\ ON STRUCTURAL BEHAVIOR OF BEAM-COLUMN SUBASSEMBLY WITH BRACE
}

\author{
Shoichi KISHIKI*, Naoya KONDO**, Satoshi YAMADA*** \\ and Takashi HASEGAWA **** \\ *Associate Prof., Structural Engineering Research Center, Tokyo Institute of Technology, Dr.Eng. \\ **Former Grad. Stud., Tokyo Institute of Technology, M.Eng. \\ *** Prof., Structural Engineering Research Center, Tokyo Institute of Technology, Dr.Eng. \\ ****Senior Researcher, Structural Engineering Dept. Building Resarch Institute, Dr.Eng.
}

The previous researches in the 1970-80s on braced-frame structures have tested isolated braces or simple subassemblages. A modern seismic design procedure of the connections which connect a brace to a gusset-plate had been established from these test results. And then, the sufficient effects of the design procedure have been proven by the damage reconnaissance of a recent earthquake. However, the majority of the previous studies has neglected the influence of the framing components and the gusset-plate connection on the system performance. In other words, effects of the differences in the connection details including the framing components are not clear. Therefore, it tends to bring many kinds of connection details to construction site in order to advance the workability improvement.

In this paper, cyclic loading tests were conducted to investigate effects of the differences in the connection details on structural behavior of beam-column subassembly with a brace. Test specimen is a beam-column subassembly which is one-fourth of a single braced-frame. A main test parameter is connection details of a brace to a gusset-plate. Practical rules of the connection design are summarized as follows:(1) a brace, a beam, and a column are connected without the eccentricity ; 2 ) pin-joint detail is used for the beam-end connections to reduce a bending moment in the weak axis of the H-shaped column. A cantilever gusset-plate, which is named specimen (a), is a simple method to satisfy the two rules. On the other hand, specimen (b), which uses a brace with the eccentricity, breaks the rule (1) in order to ensure the efficient cross section of the gusset-plate. In addition, in specimen (c), a single gusset-plate is used to combine a brace-to-column connection with a beam-to-column connection. And in specimen (d), the gusset-plate is welded to a beam and a column.

From the experiments, a decrease in the initial stiffness of the whole frame and the insufficient strength caused by the unexpected failure modes of the connection are obtained. A roughly 45-56\% decrease in the initial stiffness is observed in specimen (a) and specimen (b), because of the local deformation due to the bending moment caused by the eccentric connection. Based on the test results, the simplified evaluation model considering the local deformation as a serially-concatenated spring is proposed.

On the other hand, the unsufficient strength and the unexpected failure modes are also observed in the above specimens. In specimen (a), the lateral strength of the whole system is limited by the flexural strength of the cantilever gusset-plate. And a crack, which occurred at the beam-side toe of the gusset-plate, was growing due to the cyclic loadings and caused strength degradation of the whole system. Therefore, it indicated that the sufficient strength of the whole system was not able to expect from the cantilever gusset-plate.

(2014 年 6 月 9 日原稿受理, 2015 年 1 月 26 日採用決定 
